\title{
Diaspora and development: lessons from Somaliland
}

\section{Matthew MacGregor*, Fawzia Yusuf H. Adam and Saad Ali Shire}

The Fletcher School of Law and Diplomacy, Tufts University, 160 Packard Avenue, Medford, Massachusetts 02155-7082, USA

E-mail: matt.macgregor@gmail.com

E-mail: fawzia.adam@raadinternational.com

E-mail:saad@dahabshiil.com

${ }^{*}$ Corresponding author

\begin{abstract}
The success of the University of Hargeisa in Somaliland demonstrates how the flow of skilled migrants from the developing to the developed world - once viewed merely as brain 'drain' - may in fact be more accurately described as an imperfect circular flow of skilled workers, knowledge, finance, and development. The skilled Diaspora can invoke its capabilities, networks, and access to financial resources to catalyse economic development in the home country. In Somaliland, these factors culminated in the creation of a knowledge-based institution that has the potential to substantially contribute to the development of local human capital.
\end{abstract}

Keywords: Diaspora; development; brain drain; brain gain; migration; Somaliland; University of Hargeisa; migrant associations; remittances; economic development; knowledge transfer; skilled emigrants.

Reference to this paper should be made as follows: MacGregor, M., Adam, F.Y.H. and Shire, S.A. (2008) 'Diaspora and development: lessons from Somaliland', Int. J. Technology and Globalisation, Vol. 4, No. 3, pp.238-255.

Biographical notes: Matthew MacGregor holds his MA in International Affairs from the Fletcher School of Law and Diplomacy (Boston, USA), and his BA in International Relations and History from Tufts University (Boston, USA). His academic research focuses on the effects of migration and remittances on economic development. Professionally, he has consulted for Catholic Relief Services in Central America and worked in public health in Ecuador. He was awarded the Fletcher School's prizes for academic excellence in 2007 and 2008, and has been selected as a Henry Luce Scholar for 2008-2009. He presently lives and works in Hanoi, Vietnam.

Fawzia Yusuf H. Adam holds a Bachelor of Arts in Education from Umdurman College of Education, Sudan and a Masters of International Public Policy from the School of Advanced International Studies at Johns Hopkins University in Washington DC, USA. She is the Founder and was the first Chancellor of the University of Hargeisa, Somaliland, and the founder and CEO of RAAD TV International, a London-based television channel. She has also founded and headed numerous NGOs and women's groups in London, Kenya, and Somalia.

Saad Ali Shire is the Managing Director of Dahabshiil Transfer Services Limited. Prior to his current position, he was projects manager at Oxford House (a London charity), a business advisor at the Community Enterprise 
Development Agency in London, a National Professional Officer for the FAO and UN, a Lecturer at Somali National University and a research consultant at the World Bank. He is the founder of Burao University in Somalia/Somaliland, and a founding member of Hargeisa University. He holds a PhD and MSc in Agricultural Economics from Pennsylvania State University and Laureate (BSc) with honours from the Somali National University.

\section{Introduction}

\subsection{Human capital and the brain drain in the knowledge economy}

According to the Least Developed Countries Report (2007) by the United Nations Conference on Trade and Development (UNCTAD), the emigration of skilled workers from Least Developed Countries (LCDs) to OECD countries increased sharply during the 1990s (UNCTAD, 2007). This sharp increase is a reflection of a much longer-term trend in international labour movement - the out-migration of tertiary educated, skilled workers from the developing to the developed world. Seeking improved economic opportunities, fleeing from domestic political turmoil or persecution, and responding to demand for skilled workers within the developed world, ${ }^{1}$ millions of developing world citizens have migrated abroad in the past half century. ${ }^{2}$

For years, scholars and economists have worried about the impact of out-migration on the human capital endowment of countries in the developing world. As one of the most fundamental determinants of long-term economic growth, human capital endowment plays an important role in a country's development of domestic capabilities (UNCTAD, 2007). As such, the so-called 'brain drain' - the loss of skilled workers and the knowledge, capabilities, and human capacities that they possess - has traditionally been seen and treated as a 'curse' for economic development (Docquier et al., 2007). By losing the ability to tap into the knowledge base of tertiary educated citizens, the brain drain can decrease potential knowledge spillovers in the wider labour pool, limit the ability of governments to staff public services with educated professionals (particularly in the fields of education and health), and decrease the production of tax revenue in the sending country (Özden and Schiff, 2006). ${ }^{3}$ Early studies on the brain drain phenomenon pointed to the combined effects of out-migration on the reduction of educated manpower and its negative impact on national output (Manning, 2007). In today's 'knowledge economy', where long-term economic growth is more directly tied to a country's ability to harness its human capital for productive purposes than ever before, the impact of brain drain could be particularly damaging to the economic prospects of the poorest countries. ${ }^{4}$

\subsection{Brain gain}

More recent studies on the brain drain, however, have challenged the purely negative impacts of out-migration on the economy of the sending country. ${ }^{5}$ Rather than envisioning brain drain as a one-way street, the new brain drain literature highlights the possibility that brain drain is actually an imperfect circular flow of skilled workers, knowledge, finance, and development. Indeed, as David M. Hart explains, 
"what was once viewed simply as a brain 'drain' from developing countries to developed ones is now variously labelled brain 'strain', brain 'circulation', and even brain 'gain'." (Hart, 2006)

Whereas 'brain drain' emphasises the loss of skilled workers to the developed world (and a severed relationship between North and South), brain 'circulation' and 'brain gain' stress the maintenance of links between emigrants and their home countries that can result in productive re-circulation of knowledge, ideas, and finance. The extent to which emigration results in an increase in human capital in the home country - either through direct (return migration, knowledge transfer, remittances, investment, etc.) or indirect (increased demand for education, improved public services, etc.) methods is seen as vital to the existence and benefits of 'brain gain' UNCTAD (2007).

\section{Diaspora and development}

Of the numerous possible sources of 'brain gain', increased attention is being paid to the importance of Diasporas and their impact on home country development. This attention is somewhat of a recent phenomenon. Most traditional studies of Diasporas (particularly as they related to Africa) focused on the cultural realm, seldom delving into the complex interactions between emigrant communities abroad and development in the country of origin (Mohan and Zach-Williams, 2002). Today, the impact of Diasporas on home country development is seen largely through the lens of transnationalism and transnational communities (Levitt, 2001). ${ }^{6}$ The forces of globalisation and the revolution in communication technology have allowed migrants to remain more connected to their home communities than ever before, creating a sense of identity that transcends political and other established boundaries (Séguin et al., 2006). Mohan and Zach-Williams (2002) note that this sense of 'belonging' often "generates and enables common political, cultural or economic endeavours", among members of a Diaspora.

Members of the Diaspora contribute to home country economic development in a number of ways. At an individual level, emigrants contribute by transferring direct financial capital to their home country in the form of remittances, by returning home as skilled workers, by investing in home country business development (in the form of FDI), by funding home country entrepreneurs, and by participating in knowledge networks that seek to transfer skills. ${ }^{7}$ Foreign direct investment and financial remittances by emigrants living abroad have increased dramatically during the past few decades, and now constitute a major source of development finance (Ratha, 2003).

In addition to these individual activities, members of a Diaspora can also contribute to home country development by participating in collective formal or informal associations that organise and finance development projects. These emigrant associations act much like miniature aid agencies, identifying home country needs, selecting possible projects, and working with local actors to oversee the implementation of those projects back home. In his work on Mexican Home Town Associations (HTAs), Manuel Orozco of the Inter-American Dialogue has identified these initiatives as important new players in the international development arena that can have a beneficial impact on the economic and social development of developing world communities (Orozco and Lapointe, 2004). ${ }^{8}$ Typically comprised of a core of dedicated volunteers that draw on the resources of an extended emigrant community, HTAs are often close-knit entities made up of emigrants who hail from a similar place in the sending (and often, the receiving) country. 
The geographic ties to a specific locality back home increase the social capital that exist within the emigrant community and helps foster a shared obligation to the chosen development projects. Although many of the hometown associations are financially limited and tend to engage in small-scale development projects, Orozco argues that they have the capacity to promote important development, particularly when they partner with other public and private institutions (Orozco and Lapointe, 2004).

\section{Harnessing the Diaspora for development: identity, connectivity, and institutions}

In addition to providing support for the argument that the Diaspora can and does play an important and powerful role in development, the literature cited above also helps identify a number of enabling factors, institutional mechanisms, and underlying characteristics that may help maximise the impact of the Diaspora - particularly as it relates to collective attempts to finance and undertake development projects by informal and formal emigrant associations. First, a sense of belonging and identity - a connection with the home community - is seen as vital for Diaspora development efforts to succeed. Mohan and Zach-Williams (2002) and Henry and Mohan (2003) note that a sense of 'belonging' or 'obligation' helps generate the desire to contribute back home, either through remittances, donations, investment, participation in professional networks, or eventual return. This sense of identity is often associated with some sort of geographical focus (such as a migrant's hometown), which helps migrants recognise who the direct beneficiaries of their efforts will be.

Second, practical mechanisms for contributing to home development are needed. These include a communication infrastructure (both telecommunications and access to internet services), methods of transferring financial resources across borders, and the ability to return home or engage in the local economy. As noted by Moses Naim, the increase in global connectivity and improvements in communication infrastructure now make it easier for emigrants to stay connected, increasing their 'transnational' presence and helping to facilitate their involvement in home country development (Naim, 2002). This increased connectivity may be relaxing the geographical constraint of what Hart terms 'knowledge spillovers,' since increased communication possibilities no longer require geographical proximity for such spillovers to occur (Hart, 2006). As we will see in the subsequent Somaliland case study, increased communication ability among the Diaspora can also decrease the geographical constraint associated with emigrant associations, by allowing those associations to organise, fundraise, and operate in both a geographic as well as a 'virtual' world.

Third, harnessing the power of the Diaspora often requires institutions on the ground (in both the sending and receiving countries) that help organise emigrant communities for development purposes. Where identity and a common sense of belonging provide the motivation for action, institutional mechanisms can provide the much needed framework for getting things done. These institutional mechanisms - including formalised and informal development organisations built by and for migrants - contribute to the ability of migrants to channel their development efforts. In addition to Orozco's Hometown Associations, ${ }^{9}$ these organisations include alumni associations, religious associations, investment groups, development NGOs, and many others. ${ }^{10}$ Since emigrant associations are both formal and informal in nature, the institutions that make up those associations 
are manifest in a variety of forms, including those with traditional management structures and clearly delineated responsibilities, as well as those that revolve around a single champion (or social entrepreneur) that takes the project under his or her wing. Regardless of the type of organisational mechanism that guides the process, however, Lowell and de la Garza argue that transparent and democratic processes have the greatest chance of success (Lowell and de la Garza, 2002).

Fourth, institutional support from third-party organisations can help improve Diaspora efforts. Orozco, as well as Lowell and de la Garza, note that formal relationships with local government and other entities could improve the development impact of the Diaspora (Orozco and Lapointe, 2004; Lowell and de la Garza, 2002). Local governments can play a key role in facilitating contact among emigrants abroad, establishing programs that migrants prefer, and/or helping to push projects through obstacles at the local level (Lowell and de la Garza, 2002). Evidence from Mexico's $3 \times 1$ program, where migrant remittances are leveraged with state finances for the purpose of funding local development projects, demonstrates one possible partnership with a local governmental body. Many non-governmental organisations, including traditional development NGOs as well as new players focused specifically on harnessing the Diaspora for development, can also play an important role in maximising developmental impact (Olesen, 2002).

Finally, Orozco recognises the importance of both sending and receiving party agency (participation and control over the process) in the ultimate success or failure of Diaspora development efforts (Orozco and Lapointe, 2004). Ensuring that both sides of the development equation are actively engaged in the process can help ensure transparency, ensure the proper use of funds, better meet the specific needs of the community back home, and improve efficiency - each an important aspect of successful implementation and the achievement of a positive development impact.

\section{Lessons from Somaliland}

The subsequent case study on the Somaliland Diaspora and the University of Hargeisa sheds additional light on the questions raised above. The ability of a small group of Somali emigrants living in the UK to effectively harness the development potential of the worldwide Somali Diaspora to build a university in Somaliland not only underscores the importance of the 'brain gain' phenomenon, it also highlights a number of principle factors that can help maximise a Diaspora's ability to contribute to development. These factors - increased worldwide connectivity and improved human mobility, shared motivation, shared identity, the value of social entrepreneurship, the importance of home country and sending country agency, and the role of communication infrastructure - all played a major role in the success of the University of Hargeisa. Each factor helped turn the 'brain drain' into a quintessential 'brain gain' by investing in the creation of a knowledge-based institution (a university) in the developing world.

\section{Somalia, Somaliland, migration and remittances: the historical context}

The history of Somalia and Somaliland is a complicated mix of colonialism, state collapse, civil war, state building, and underdevelopment, each of which has influenced 
internal and international Somali migration patterns. The collapse of the post-colonial Somali state in 1991, followed by the much publicised UN humanitarian and peace keeping interventions in the mid-1990s, set northern and southern Somalia on separate trajectories. Since the collapse, a large part of northern Somalia (Somaliland) has undertaken a process of democratic state building, claiming independence from Somalia and consistently seeking (until now without success) international recognition as an independent state. Southern Somalia, in the meantime, has fallen deeper and deeper into chaos, violence, instability, and the many other grievances associated with failed states.

Contemporary Somali migration patterns are a reflection of the state's experience with unstable political environments and repeated periods of widespread violence, as well as a general lack of economic and educational opportunities. Massive forced migration (both internal and international) occurred during the Ogaden War between Somali and Ethiopia in the 1980s, during the years of the civil war between north and south, and after the subsequent state collapse in 1991. An estimated 1 million Somalis fled the country during the fighting in southern Somalia in 1991, both to neighbouring countries in the region and abroad. Those who could pay their way, as well as those who were lucky enough to receive political asylum, fled to Western Europe and North America, reinforcing the already existing and relatively large Somali Diaspora community in Canada, the USA, the UK, Italy, Holland, Sweden, Denmark, Norway, Finland, and Australia (Gundel, 2002). ${ }^{11}$

The desire for further economic and educational opportunities has also contributed to the Somali dispersion. Beginning in 1973, Somalia became a major labour exporter to the Gulf States. It is estimated that more than 350,000 migrants left Somalia throughout the 1970s and 1980s to seek economic advancement in the more prosperous Gulf region, and thousands more moved abroad to Western Europe and North America for the purpose of furthering their education in Western institutions or pursuing economic opportunities in the developed world. The combined effect of forced migration and migration for economic and educational purposes has resulted in a significant presence of Somalis abroad (Gundel, 2002). It has also contributed to the out-migration of a large number of Somalia's skilled workers. According to the United Nations Conference on Trade and Development, the total out-migration rate of all Somalis during the 1990s was $14.2 \%$. However, the total out-migration rate of skilled Somalis - those with a tertiary education - was near 50\% (UNCTAD, 2007).

Since the massive movements of Somali workers to the Gulf States in the 1970s, remittances have constituted a very important part of the Somali economy and an essential aspect of household income. During the late-1970s and 1980s, much of the money remitted came from workers in the Arab Gulf States. The conflict related refugee flows to Western Europe and North America in the late-1980s and 1990s; however, changed the overall pattern of remittance flows and increased the importance of the Somali Diaspora in the developed world (Gundel, 2002). This importance of the Diaspora, particularly in Somaliland, can be seen not only in the level of remittances sent to the region but also in the circular flow of knowledge, skills, and investments that combine to influence economic development of the region. The creation and development of the University of Hargeisa, to which this paper now turns, is a case in point. 


\section{The university of Hargeisa}

Looking at the University of Hargeisa (UoH) today, it is hard to imagine that just ten years ago the idea to create a full-fledged institution of higher learning in the Somaliland capital was still only a dream in its initial stages. Less than a decade after it was founded, the UoH boasts an enrolment of more than 3000 students, seven faculties (business administration, science, law, Arabic and Islamic Studies, medicine, education, and ICT and distance learning), five institutes and centres, formal relationships with a wide variety of American and African educational institutions, more than 100 professors, and over 400 graduates with Bachelor Degrees. ${ }^{12}$ Graduates are employed throughout the private, public, and non-governmental sectors of the unrecognised territory, and the university has consistently been one of Somaliland's most important and largest employers. ${ }^{12}$

But perhaps even more astounding than its rapid development and success are the origins of its creation. Founded in 1999, the UoH is to a large extent the product of the skilled Somali Diaspora that migrated abroad before, after, and during the civil war and subsequent state collapse that tore apart the Somali Republic in the early 1990s. Organised, managed, supplied, and (almost completely) funded by the Diaspora community living abroad, the UoH is an excellent example of the positive impact the Diaspora can have on home country development. Motivated by their common identity, propelled by their own capabilities, and assisted by recent trends and advances in telecommunications, two members of the Somaliland Diaspora in London were able to harness the resources of the larger Somaliland community and effectively channel their efforts towards the creation of a knowledge-based institution back home.

\subsection{Motivation}

The chief architect of the University of Hargeisa's success was Fawzia Adam, the founder and first chancellor of the university and a Somaliland native who migrated to London in 1995. A graduate of the School of Advanced International Studies at Johns Hopkins University in Washington, DC, since the end of the Somali civil war Adam was sporadically engaged in Somaliland development activities, working to provide resources and procure supplies for some of the region's financially constrained secondary schools. The daughter of one of the most influential people in Somaliland education, Adam had long recognised the importance of education and its critical link to economic development. But it was not until a visit home in 1997 that she decided to embark upon the creation of a university. While visiting one of the high schools, she was supporting in 1997, Adam had a particularly moving conversation with a then Somaliland teen. After giving a very emotional speech about the limits of a Somaliland high school degree, the teen asked, "Where do we go from here ... what do we do next?" The frustration associated with the lack of educational opportunities for Somaliland students solidified Adam's desire to create Hargeisa's first university - a long-time dream of her late father.

Adam's realisation that the lack of educational opportunities limited the ability of Somaliland students to utilise and develop their skills was echoed by Dr. Saad Shire, another member of the Somaliland Diaspora in London and Adam's chief collaborator on the UoH project. According to Dr. Shire, what motivated him and Adam above all was the situation that existed in Somaliland at the time. After years of chaos and an absolute lack of institutions of higher education in Somaliland, both Shire and Adam often 
wondered where the territory was going to get its next generation of doctors, teachers, and other professionals - each of whom would play an important role in Somaliland's future. This lack of educational opportunities, they realised, created a vicious circle of limited opportunity and low levels of professional capacity that was negatively affecting Somaliland's prospects for future development.

This desire to provide increased educational opportunities for Somaliland students was coupled with a profound sense of the role higher education can play in catalysing economic development. A graduate of Penn State University, where he received his Masters and $\mathrm{PhD}$, Dr. Shire was convinced that creating the university would not only help improve the stock of human capital in the country, but also help create an 'intellectual hub' around which business, entrepreneurship, and development could prosper. Adam and Dr. Shire recognised the importance of creating a sort of intellectual hub in Hargeisa that could bring the best of the human capital stock in the country at the time together, and pass that knowledge along to the next generation.

Embedded within their desire to improve the educational opportunities available in Somaliland was a proactive attempt to ensure that the $\mathrm{UoH}$ would not become merely a 'white elephant' - an institution disconnected from the actual development of the country. According to Dr. Shire, the two administrative councils that guided the creation of the $\mathrm{UoH}$ in its early days spent a considerable amount of time designing the curriculum and overall organisation of the university in a manner that would maximise its development impact. Having worked as a professor of planning in the agriculture department of the Somali National University in Mogadishu, Dr. Shire had seen firsthand the chasm between educational institutions and the real world that often plagues the traditional university-society relationship. The $\mathrm{UoH}$, he concluded, should focus its efforts on ensuring that academic and professional pursuits were integrated, and that the university embodied an entrepreneurial spirit. According to Dr. Shire, a proactive effort was made to structure the curriculum and mentality of the university in a way that contributed to national development. That mentality was underscored by an effort to teach students not just how to get a job, but to think about how they could use their knowledge and the preparation that they have learned to employ themselves.

\subsection{Early difficulties}

Despite their own personal conviction, Adam and Dr. Shire quickly realised that the creation of the UoH was going to be anything but easy. Looking for institutional support of the initiative, Adam approached a wide variety of development, international and philanthropic organisations to discuss the project (including the EU, World Bank, and international NGOs) without success. Many of the organisations, Adam noted, were reluctant to support the creation of an institution of higher learning, arguing that it was not appropriate in a country with such low levels of development. What was needed they told her was primary schools and increased literacy rates, not a university.

Dr. Shire's attempts to raise funds for the project were frustrated as well. According to Dr. Shire, the general response was that literacy and primary education should be the focus, an argument to which he partly subscribed. Dr. Shire believed, however, that the educational system in Somaliland would not be able to catalyse true development without a holistic approach that allowed for upward educational mobility of the general population. As Dr. Shire explains, 
"to make the most of primary education, you must have secondary education, and to make the most of secondary education, you need to have higher education ... they are interconnected. It's like a vehicle ... and for the vehicle to move you need the wheels, the axles, the engine, and the steering ... higher education provides the steering and the engine."

Having failed to garner support from the international community, Adam and Dr. Shire turned to local actors within Somaliland and the Somali Diaspora to generate the support they needed, relying both on their personal networks and the web of Somaliland migrant communities living in the developed world. It was this combination of local and international support that allowed Adam and Dr. Shire to compliment their personal efforts and move forward with the project.

\subsection{The hardware and software: building a university from the ground up}

Committed to the project despite the lack of institutional support, Adam and Dr. Shire turned their attention to outlining exactly what would be needed to make the university a reality, as well as what organisational mechanisms would ensure that the process advanced smoothly, increasing the likelihood of success. Building a university meant that they would not only need the physical infrastructure (the 'hardware') - buildings, tables, desks, chairs, books, computers - but also the intellectual infrastructure (the 'software') - a university constitution, business plan, curriculum, mission statement, and professors. What was needed, described Adam, was not only the 'what', but also the 'how'.

The first order of business was establishing an organisational structure through which both the Diaspora community abroad and local actors in Hargeisa could coordinate, participate, and establish ownership of the process. Adam recognised that the success of the project would require constant interaction and coordination amongst all of the actors, particularly the local business, political, and other forces in Somaliland itself. To coordinate these multiple players, two councils or 'steering committees' were established, one in London (made up of members of the Diaspora) and another in Hargeisa (composed of business leaders, members of the educated elite, former civil servants from the previous government, and members of local women's groups). Every decision taken by the council in London was discussed and approved by the council in Hargeisa, creating a two-tiered system of constant participation that effectively balanced the interests of the disparate stakeholders. Adam acted as a courier for the two councils, frequently travelling back and forth from London to Hargeisa to facilitate decision-making.

According to Dr. Shire, the two committee structure played an essential role in helping to build trust amongst the various actors. It led to the creation of a credible support system on the ground, and helped 'sell' the idea of the university to the Diaspora community abroad. Even though much of the work was done in an informal nature, the centralised committee structure helped promote local involvement and ensure transparency throughout the process. 


\subsection{Harnessing local and international supporters: business, local government, and the Diaspora}

With the organisational structure being intact, Adam and Dr. Shire worked to generate support amongst as many actors as possible. Adam used her father's contacts to solicit support for the university from the government in Somaliland. A letter to then President Higal from her father helped Adam secure a building that would serve as the university grounds - an old secondary school that was which was originally built by the European Union in 1967. To Adam's shock, however, the building was home to 210 squatter families - refugees who had taken up residence everywhere, from the classrooms, to the offices, to the bathrooms. When she arrived in Somaliland to view the site, she found 956 people occupying the compound, many of whom were armed. Unwilling to have them forcefully removed, Adam lobbied for a year to convince the mayor of Hargeisa to provide the squatters with land. After several rounds of consultations, the mayor agreed. In addition to the physical complex, Adam convinced the local government to provide 1000 dollars a month for the project (used largely to pay for security in the building). The initial government donation functioned as seed capital that served as the basis of the university's finances during the initial stages of development.

Adam also reached out to the local businesses in Hargeisa. According to Dr. Shire, the local businesses community was intrigued by the prospect of having a local university, an institution that could help increase the skill sets of the local workforce and improve the quality of workers that provided important public services. According to Dr. Shire, since many of the educated persons in Somaliland found employment in the public sector before the collapse of the Somali state, it was the business community's initial interest in improving the effectiveness of the public workforce that underwrote their support for the university. Over time, Dr. Shire hoped that the presence of the university would stimulate a greater demand for highly educated workers within the private sector as well.

In the initial stages, a wide variety of the local businesses in Hargeisa provided financial and material support to help renovate the dilapidated building that would house the UoH. On Adam's suggestion, each business adopted a section of the university complex and was responsible for its clean up, upkeep, and renovation. Other businesses, including Dahabshil, a major remittance house in Somaliland and one of the largest private sector companies, now provide financial support. These various roles of the business community were complimented by a wide array of support from other local interests, including the defence ministry and the military (who helped with renovations), women's groups, and local professionals.

\subsection{Engaging the Diaspora}

The efforts of local businesses and local governmental actors notwithstanding, by far the most important source of support - financially, materially, and organisationally - came from the Somaliland Diaspora and individual Somaliland communities living abroad. In addition to the central roles played by Adam and Dr. Shire, the Diaspora contributed to the $\mathrm{UoH}$ in a myriad of ways, from raising money through local community organisations, to providing material support, contributing personal finances, and advocating on behalf of the university at home and abroad. The London council, headed by Adam, was chiefly responsible for fundraising and organising the Somaliland 
communities in London and beyond. When contributions came in the form of in-kind donations, they would then be shipped directly to local counterparts in Somalia - paid for by funding that Adam was able to raise in London. The process was an intriguing mix of engagement with local Somaliland and non-Somaliland communities in the developed world, and local support by government actors within Somaliland itself. Whether it was a fundraising effort by Somaliland dancers in London or the provision of petrol for transportation of supplies within Somaliland, there was a constant effort on both sides of the Diaspora and development equation that helped facilitate the university's success.

After the first few rounds of shipments from London, the Somaliland communities in Canada, Washington, California, and throughout the world began engaging in the same process on their own. One of the Somaliland communities in Sweden convinced the mayor of the city of Falkenbury to donate furniture from an old high school. 700 chairs, 700 desks and a wide variety of other school necessities - including blackboards - made their way to Hargeisa, organised by the Somaliland communities abroad and paid for through a combination of personal donations and traditionally fundraising. Groups of Somali singers staged benefit concerts in London to pay for the University's latrines. Somalis living in Kuwait sent computers. It was this combination of material and financial support that allowed Adam to supply the university with the necessary resources to get it up and running. ${ }^{13}$

These financial contributions, however, were just one part of the equation. Contrary to what one might expect, Adam believed that the strength of the Somaliland Diaspora's contribution to the project lie not only in their financial assistance, but also in their non-financial efforts. It was the coordination and organisation that allowed the university to thrive, she noted, not just the financial support that the various actors in the Disapora were able to provide.

\subsection{The enabling factors: communication, mobility, and identity}

The efforts of Adam, Dr. Shire, and the individual Somaliland community groups that organised, financed, and shipped supplies to the UoH were aided significantly by a variety of 'enabling factors' that helped influence the ultimate success of the worldwide movement spearheaded from London. The first 'enabling factor' was the way in which changes in communication infrastructure - particularly the prominence of e-mail and the advent of cyberspace forums - allowed Adam to coordinate communication amongst the various Somaliland groups throughout the globe. Adam utilised the 'Somaliland Forum' - an internet platform that brought together the global Somaliland expatriate community, as the principal means of communication. Cyber conferences were held that allowed Adam to spread the word about the $\mathrm{UoH}$, as well as coordinate individual efforts by the various Somaliland communities dispersed throughout the world. According to Adam, from Australia to Glasgow to Africa, everyone was connected at the same time, allowing the Hargeisa founders to decide together the steps they needed to take.

The increase in the availability of communication infrastructure made it less cost prohibitive to coordinate globally, helping Adam generate the necessary support amongst the geographically dispersed Diaspora in the developed world. In addition, the increased ability to move throughout the globe allowed Adam to visit Somaliland communities worldwide, while simultaneously maintaining close connections with Hargeisa and the local council back home. From 1997 to 2000, Adam made seven trips to Hargeisa, financed almost completely out of her own pocket. 
These improvements in communication technology decreased the logistical challenges of building the $\mathrm{UoH}$ by easing the coordination required to manage a global community of actors. But it was the common sense of identity and nationalism that many members of the Somaliland Diaspora felt toward the UoH project that played a principal role in binding those widely dispersed actors together. According to Chukwu Emeka, the Executive Director of the London-based African Foundation for Development (AFFORD) and a person who has studied the Hargeisa case, one of the reasons that Adam and Dr. Shire were so successful in garnering support amongst the Somali Diaspora related to the particular nation building context within which the University of Hargeisa project was conceived, developed, and implemented. Emeka believes that the level of consensus and motivation achieved for the UoH project was at least partly a result of the more general Somaliland drive for recognition and legitimacy. According to Emeka,

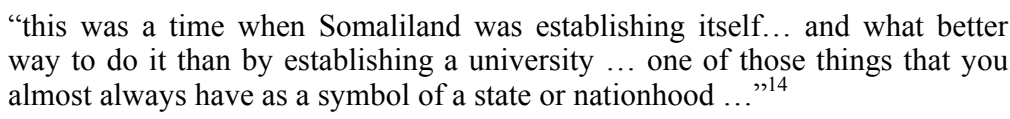

\subsection{A success story}

Each of these factors contributed to the ultimate success of the University of Hargeisa. When it opened its doors for the first time in 2000, thousands of people sat for exams, many of them Somali students who returned home from abroad to attend. ${ }^{15}$ Since then, even the tremendous growth of the university - from 200 students, 10 professors and 1800 books at its conception to 3400 students, over 100 professors and 25,000 to 30,000 books today - has been unable to keep pace with demand. Classes are full from early morning until late in the evening, and space limitations have forced some students to have to wait to enrol. ${ }^{16}$ According to Adam, the UoH is now treated as the 'jewel of the crown'. Funding has flowed in from the UNDP and the Islamic Bank, and the university has even received international acclaim for its success.

UoH graduates now occupy important positions within Somaliland and Hargeisa, as accountants, financial officers, managers, teachers, lawyers, and doctors. One observer noted how the University of Hargeisa has fundamentally changed the way that NGOs and INGOs staff their positions in Somalia. Whereas most vacancies used to be filled by importing Kenyan or Ethiopians, those same positions are now filled by locals - many of them UoH graduates. ${ }^{16}$ And perhaps most astonishingly, since its creation in 2000 the UoH has served as the model for two other universities constructed in Somaliland, funded and organised largely through the work and coordination of the Diaspora and in association with Dr. Shire himself. ${ }^{17}$ Today, as the message from the Vice Chancellor on the UoH website contends, the University of Hargeisa is posed to help Somaliland take advantage of the "knowledge economy of the 21 st century, where economic growth and social outcomes will depend on the skills of individuals and communities". ${ }^{18}$

\section{Development and the Diaspora: lessons and policy implications from the university of Hargeisa case}

The success of the University of Hargeisa case points to a number of important conclusions about the role the Diaspora can play in spurring development in the home 
country, and helps further our understanding of the way in which the 'brain drain' concept should be modified. It also points to a variety of policy implications that deal with the way in which developing world governments should engage, support, and work with their skilled emigrant communities abroad.

\subsection{Think beyond brain drain}

First and foremost, the Hargeisa case points to the need to re-conceptualise our understanding of skilled migration from developed countries. The out-migration phenomenon is not simply a one-way process with clear winners and losers, particularly when emigrants maintain close ties to the sending country. Whether or not Adam, Dr. Shire, and the Somaliland emigrants could have contributed more to the development of Somaliland than they did through the UoH had they not emigrated in the first place is an empirical matter beyond the scope of this paper. What is clear, however, is that the temporary loss of productivity associated with their emigration was at least partly offset by their investments in the University of Hargeisa, and the creation of an institution that has the potential to increase the level of human capital and produce positive, long-lasting benefits in Somaliland for generations to come. The principal role played by members of the Somaliland Diaspora in the University of Hargeisa's success, thus, is a clear example of the need to conceptualise the emigration of skilled workers from the developing world as something far more complex than simple, one-way 'brain drain'.

\subsection{Concentrate on harnessing talent, not controlling it}

Rather than viewing the emigration of skilled workers as something that should be prevented, the UoH case argues that governments in the developing world should focus on ways by which they can maximise the impact of their communities, whether or not those communities are within a country's sovereign borders or living abroad. By re-conceptualising the idea of a 'citizen' within a transnational lens, governments will be able to more easily identify strategies through which they can tap the development potential of the Diaspora for productive purposes. Emigrants, after all, are rarely lost - particularly those that still share a strong identity with their home country. Given the drastic changes in the way in the world can and does communicate and connect today, geography should be viewed less as an inhibiting factor and more as a mere complexity that can be overcome.

Re-conceptualising what the emigration of skill workers actually means for home country development will allow governments to craft policies that can harness the development potential of the Diaspora without necessarily controlling the flow of talent. These policies should look beyond the financial realm and migrant remittances. Although much of the existing literature focuses on tapping Diaspora communities for financial investments, the University of Hargeisa case also demonstrates the role that skilled emigrant communities can play in largely non-financial investments in their home countries.

\subsection{The role of skilled emigrants}

Orozco's discussion of Hometown Associations (summarised above) rightly points out the limited impact that such groups often have on home country development, due in 
large part to their limited time, resources, and capabilities. His discussion, however, largely focuses on groups of unskilled workers. The UoH case demonstrates the potential ways in which skilled Diasporas - groups that bring a different set of experiences, contacts, skill sets, and capabilities to the table than their unskilled counterparts - can organise and implement more complicated projects. As was the case with the UoH, these projects may serve as important catalysts for economic development. The importance of the 'skilled Diaspora' is evidenced not only by Adam and Dr. Shire's intellectual engagement with the university and their ability to ensure its creation, but also by the connections that they had with important political and other actors in the home country that improved the university's chance of success. The skilled Diaspora, therefore, should not be understood only as a potential source of private sector investment, but also as an 'intellectual' development actor that may be able to help the home country take important strides in non-financial realms as well.

Despite the potential impact of these "intellectual development actors", efforts by sending country governments to harness the skilled Diaspora for development purposes should not be limited to a traditional non-governmental, project-led development model. As Chukwu-Emeka Chikezie of the AFFORD Foundation rightly points out,

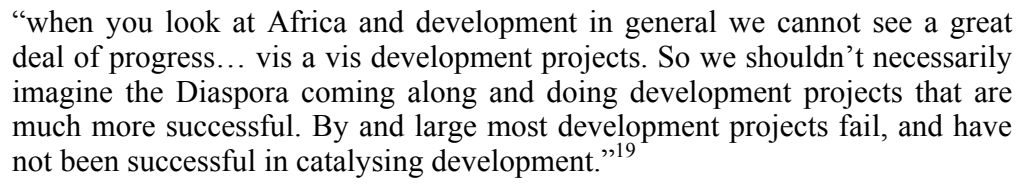

Instead, Chikezie argues, a more ample vision of what the Diaspora is capable of accomplishing is needed; a vision that focuses on all of the ways in which the Diaspora can contribute to home country development, from remittances and personal financial contributions, to investment and entrepreneurial activities, skills transfer, knowledge exchange, political influence, or even their consumer power to consume products and services from their countries and regions of origin. ${ }^{19}$

\subsection{Support the 'social entrepreneurs' of the Diaspora}

This amplified vision of what the Diaspora is capable of contributing to home country development points to the final, and perhaps most important, lesson learned and policy implication of the UoH case. The success of the University of Hargeisa demonstrates that there is no one, single organisational mechanism through which investments in development can occur. Adam and Dr. Shire's efforts were not part of an official development effort, complete with a regulated administrative structure. Nor were they devoid of any organisational framework. Rather, as Chukwu Emeka Chikezie of AFFORD explains, the UoH success story was a 'hybrid' between largely informal processes, "driven by key personalities that had a certain combination of passion and vision, [along with] some of the emerging state structures on the ground". ${ }^{19}$ The model that facilitated the creation of the University of Hargeisa, thus, cannot be put into any one box. Nor is it likely to be replicated. But it does demonstrate that sending country governments could more effectively harness the development potential of their Diaspora by looking to proactively support the efforts of expatriate skilled workers that operate through 'social entrepreneurship' models - models that do not require a specific administrative design. Given their resources and desire to contribute back home, it seems 
likely that many of these social entrepreneurs could have a significant impact with minimal assistance, as was the case with Adam, Dr. Shire, and the UoH.

\section{Conclusions: re-conceptualising the Diaspora's role in development}

Traditionally, scholars have focused on the negative impacts out-migration can have on the human capital endowment of the developing world. Recent scholarship, however, has highlighted the possibility that the brain drain is not necessarily a one-way flow of talent, but rather an imperfect circular flow of people, knowledge, skills, and finances that may have both positive and negative consequences for home country development. In recent decades, the possibility that emigrant communities living in the developed world may be able to contribute to development in the home country has increased, due in large part to improved and less expensive telecommunication capabilities and improved worldwide mobility, as well as the more general tendency towards increased global connectivity. Given the recent increases in out-migration from the developed world, it seems unlikely that developing world countries will be able to stem the tide of skilled immigrants, particularly if levels of development at home remain stagnant and access to education and economic opportunities remain concentrated in the developing world. These trends, therefore, point to the need for developing world governments to more effectively enact policies that harness the capabilities of the skilled Diaspora, rather than trying to artificially control the flow of talent.

The University of Hargeisa case and the ability of the Somaliland Diaspora to organise, implement, manage, and finance the creation of a knowledge-based institution in the developing world is an important evidence of the possible development impacts of the Diaspora and the 'brain gain' phenomenon. As demonstrated by the UoH case and the work of Fawzia Adam and Dr. Saad Shire, members of the skilled Diaspora can invoke their capabilities, networks, and access to financial resources to catalyse economic development in the home country. Beyond remitting money back home, these skilled emigrants may be capable of more complex initiatives that require not only careful coordination and administration, but intellectual engagement. In the UoH case, the combination of improved telecommunication, the personal capabilities of Adam and Dr. Shire, and the common sense of identity that attracted members of the Diaspora to the $\mathrm{UoH}$ project culminated in the creation of a knowledge-based institution that has the potential to throw the brain drain phenomenon on its head.

By envisioning the Diaspora not as a lost good, but as an important social and economic asset of the home country, governments will be able to more effectively craft policies that maximise the Diaspora's impact. Where governments can play a positive role in contributing to this impact, they should. This could entail supporting the work of the Diaspora financially, providing them with contacts, helping them mobilise resources, or even partnering with them on development projects or financial investments. As long as government efforts increase (rather than stifle) the creative efforts of the Diaspora and facilitate their involvement with the home country, they have the potential to multiply the impact of one of their most important resources - their transnational community. 


\section{References}

Brinkerhoff, J. (2006) Diasporas, Skills Transfer, and Remittances: Evolving Perceptions and Potential, Asian Development Bank.

Carrington W.J. and Detragiache, E. (1998) How Big is the Brain Drain?, IMF Working Paper, IMF Research Department, Washington, DC.

Docquier, F., Lohest, O. and Marfoulk, A. (2007) Brain Drain in Developing Countries, The World Bank Economic Review, Oxford University Press, Vol. 21, No. 2, pp.193-218.

Gundel, J. (2002) 'The migration development nexus: Somalia case study', International Migration, Vol. 40, No. 5, pp.255-281.

Hart, D.M. (2006) 'Managing the global talent pool: sovereignty, treaty, and intergovernmental networks', Technology and Society, Vol. 28, pp.421-434.

Henry, L. and Mohan, G. (2003) 'Making homes: The Ghanaian Diaspora, institutions, and development', Journal of International Development, Vol. 15, pp.611-622.

Juma, C. and Yee-Cheong, L. (2005) Innovation: Applying Knowledge in Development, The UN Millennium Project. Task Force on Science, Technology, and Innovation, The United Nations Development Program (UNDP).

Kapure, D. and McHale, J. (2005) Give us Your Best and Brightest: The Global Hunt for Talent and Its impact on the Developing World, Center for Global Development, Washington, DC.

Least Developed Countries Report (2007) United Nations Conference on Trade and Development, United Nations.

Levitt, P. (2001) The Transnational Villagers, University of California Press, Berkeley, Los Angeles and London.

Lowell, B.L. and de la Garza, R.O. (2002) 'A new phase in the story of remittances', in Lowell, B.L. and de la Garza, R.O. (Eds.): Sending Money Home: Hispanic Remittances and Community Development, Rowman and Littlefield Publishers.

Lowell, B.L. (2001) Migration of Highly Skilled Persons from Developing Countries: Impact and Policy Responses, International Labour Office, International Migration Branch, Geneva.

Lowell, B.L. and Gerova, S.G. (2004) Diaspora And Economic Development: State of Knowledge, The World Bank, Washington, DC.

Manning, C. (2007) 'Brain drain and brain gain', United Nations Conference on Trade and Development (UNCTAD), Least Developed Countries Background Paper, United Nations.

Meyer, J-B., Bernal, D., Charum, J., Gaillard, J., Granes, J., Leon, J., Montenegro, A., Morales, A., Murcia, C., Narvaez Berthelemot, N., Parrado, L.S. and Schlemmer, B. (1997) 'Turning brain drain into brain gain: the Colombian experience of the diaspora option', Science, Technology, and Society, Vol. 2, pp.286-315.

Mohan, G. and Zack-Williams, A.B. (2002) 'Globalization from below: conceptualizing the role of the african diasporas in Africa's development', Review of African Political Economy, June, pp.211-236.

Naim, M. (2002) 'The New Diaspora: new links between émigrés and their home countries can become a powerful source for economic development', Foreign Policy, July-August, Carnegie Endowment for International Peace.

Ndofor-Tah, C. (2000) Diaspora and Development: Contributions by African Organizations in the UK to Africa's Development, Report commissioned by AFFORD, The African Foundation for Development, London.

Olesen, H. (2002) 'Migration, return, and development: an institutional perspective', International Migration, Vol. 40, No. 5, pp.125-150.

Orozco, M. (2003) Hometown Associations and their Present and Future Partnerships: New Development Opportunities?, Inter-American Dialogue. Report Commissioned by the US Agency for International Development (USAID), Washington DC. 
Orozco, M. (2005) 'Transnationalism and development: trends and opportunities in Latin America', in Maimbo, S.M. and Ratha, D. (Eds.): Remittances: Development Impact and Future Prospects, World Bank, Washington DC.

Orozco, M. and Katherine, W. (2005) Hometown Associations and Development: A Look at Ownership, Sustainability, Correspondence, and Replicability, Inter-American Dialogue, Washington, DC.

Orozco, M. and Lapointe, M. (2004) 'Mexican hometown associations and development opportunities', Journal of International Affairs, Vol. 57, No. 2, pp.31-52.

Özden, Ç. and Schiff, M. (Eds.) (2006) International Migration, Remittances and the Brain Drain, World Bank, Washington DC.

Patterson, R. (2006) 'Transnationalism: diaspora-homeland development', Social Forces, Vol. 84, No. 4, pp.1891-1907.

Ratha, D. (2003) 'Worker's remittances an important and stabile source of development finance', Global Development Finance: Striving for Stability in Development Finance, The World Bank, Washington DC, pp.157-175.

Saxenian, A.L. (1999) Silicon Valley's New Immigrant Entrepreneurs Public Policy Institute of California.

Saxenian, A.L. (2002) 'Brain circulation: how high-skill immigration makes everyone better off', The Brookings Review, Vol. 20, No. 1, Winter, pp.28-31.

Séguin, B., State, L., Singer, P.A. and Daar, A.S. (2006) 'Scientific diasporas as an option for brain drain: re-circulating knowledge for development', Int. J. Biotechnology, Vol. 8, Nos. 1-2, pp.78-90.

Sriskandarajah, D. (2005) Migration and Development, A paper prepared for the Policy Analysis and Research Program of the Global Commission on International Migration, Institute for Public Policy Research, London.

Stark, O. (2002) The Economics of The Brain Drain Turned on its Head, World Bank, Washington DC.

\section{Notes}

${ }^{1}$ For more information on the causes of migration, including the demand for high-skilled workers from the developing world, see: Kapure and McHale (2005); UNCTAD (2007).

${ }^{2}$ For more information on the exact size of the brain drain and current migration patterns, see: Carrington and Detragiache (1998).

${ }^{3}$ See also: Brinkerhoff (2006).

${ }^{4}$ For more information on the importance of knowledge in development, see: Juma and Yee-Cheong (2005).

${ }^{5}$ For further information on the new brain drain literature, see: Lowell and Gerova (2004), Saxenian (1999, 2002), Stark (2002) and Patterson (2006).

${ }^{6}$ For more discussion on transnationalism and transnational communities, see: Orozco (2005) and Levitt (2001).

${ }^{7}$ For further information on the ways in which migrants contribute individually to home country development, see: Lowell (2001), Saxenian (2002), Naim (2002), Séguin et al. (2006) and Meyer et al. (1997).

${ }^{8}$ For further information on collective remittances and hometown associations, see: Orozco (2003); Orozco and Lapointe (2004); Orozco and Welle (2005). 
${ }^{9}$ In the case of hometown associations, Orozco identifies a variety of specific factors that may help turn identity and belonging into tangible development through institutions, although he stops short of labelling them as 'determinants' of that success. Principal among these is the organisation's capabilities and resources, as well as its age (how long it has been in operation), specific objective, and the strength of the core group of volunteers who often play an integral role in an organisation's activities. For further discussion, see: Orozco and Lapointe (2004).

${ }^{10}$ For further discussion of the types of organisations that engage in home country development, see: Mohan and Zach-Williams (2002) and Ndofor-Tah (2000).

${ }^{11}$ For a detailed discussion of migration and development in Somaliland, see: Gundel (2002).

${ }^{12}$ Written correspondence and responses to a questionnaire with Abdirahman Suleiman Jama of the Norwegian Refugee Council and graduate of the University of Hargeisa, Somaliland. 12 November 2007.

${ }^{13}$ For a short description of the UoH project and the various types of support of the Somaliland Diaspora, you may also see: Sriskandarajah (2005).

${ }^{14}$ Authors' interview with Chukwu-Emeka Chikezie, Executive Director, the Afford, 11 October 2007.

${ }^{15}$ See also: Sriskandarajah (2005).

${ }^{16}$ Written correspondence and responses to a questionnaire with Abdirahman Suleiman Jama of the Norwegian Refugee Council and graduate of the University of Hargeisa, Somaliland. 12 November 2007.

${ }^{17}$ The other universities are: Berbara College and Burao University.

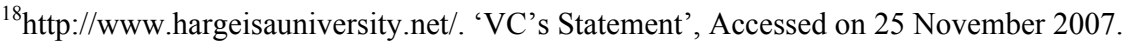

${ }^{19}$ Authors' interview with Chukwu-Emeka Chikezie, Executive Director, the AFFORD, 11 October 2007. 